\title{
Importance of Diffusion Process on the Fatigue Life of Steel
}

Zbyněk Studený, David Dobrocky, Zdenek Pokorny

Department of Mechanical Engineering, University of Defence, Kounicova 156/65, 66210 Brno, Czech Republic., Email: zbynek.studeny@unob.cz,david.dobrocky@unob.cz, zdenek.pokorny@unob.cz

Evaluation of the diffusion process is the plasma nitriding technology in connection with an increase of fatigue life of steel. For experiments steels 41CrAlMo7-10 and 34CrNiMo6 were selected. The equivalent of mentioned steel is material no. 1.8509 and no. 1.6582. Plasma nitriding technology belongs to the group of chemical-heat treated process. This process includes the saturation of nitrogen to the core of material. Plasma nitriding technology is effective method usage in practise especially in order to increase the surface hardness, corrosion resistance and fatigue strength. The experimental material samples were heat treated and subsequently plasma nitride. Fatigue bending rotation tests were the major part of the experiments. According to the principle of the experiment the rotation velocity was determined as constant and the load of samples was going down. The experimental measurement were stopped in case of fracture or after $10^{7}$ cycles without damage. Fatigue life of the steel depends on the thickness of a diffusion nitrided layer. This thickness was evaluated by using the microhardness measuring from the surface to the core of the material. The results of experiments shows that these steels are suitable for increasing fatigue life after the plasma nitriding process.

Keywords: Fatigue live, plasma nitriding technology, Wöhler curves

\section{Acknowledgement}

The paper has been prepared thanks to the support of the project The Development of Technologies, Design of Firearms, Ammunition, Instrumentation, Engineering of Materials and Military Infrastructure "VÝZBROJ (DZRO K201)." and "Surface technology in applications special techniques SV16-216."

\section{References}

[1] DOBROCKÝ, D., KUSMIČ, D. (2015): The assessment of selected mechanical properties of steel after application of plasma nitriding. Manufacturing Technology, vol. 15, no. 3, p. 307-315. ISSN 12132489

[2] POSPÍCHAL, M., DOVŘÁKOVÁ, R., STUDENÝ, Z., POKORNÝ, Z. (2015): Influence of initial carbon concentration on nitride layers. Manufacturing Technology, vol. 15, no. 5, p. 889-893. ISSN 12132489

[3] POKORNÝ, Z., STUDENÝ, Z., POSPÍCHAL, M., JOSKA, Z., HRUBY, V. (2015): Characteristics of plasma nitrided layers. Manufacturing Technology, vol. 15, no. 5, p. 403-409. ISSN 12132489

[4] JONŠTA, P., VLČKOVÁ, I., JONŠTA, Z. (2016): Material Analysis of Nickel Superalloy for Military Technology. Manufacturing Technology, vol. 16, no. 2, p. 348-354. ISSN 12132489

[5] KLANICA, O., SVOBODA, E., JOSKA, Z. (2015). Changes of the Surface Texture after Surface Treatment HS65-2-5 Steel. Manufacturing Technology, vol. 15, no. 1, p. 47-53. ISSN 12132489

[6] MUGHRABI, H., (2010): Fatigue, an everlasting materials problem - still en vogue. Procedia Engineering 2, p. 3-26.

[7] GiANCANE, S., NOBILE, R., PANELlA, F.W., DATTOMA, V., (2010): Fatigue life prediction of notched components based on a new nonlinear Continuum Damage Mechanics model. Procedia Engineering 2, p. 13171325

[8] SUGIMOTO, K., FIJI, D., YOSHIKAWA, N., (2010): Fatigue strength of newly developed high-strength low alloy TRIP-aided steels with good hardenability, Procedia Engineering 2, p. 359-362

[9] SKOČILASOVÁ, B., SKOČILAS, J. (2013). Simulation of Liquid Flow in Pipe. Manufacturing Technology, vol. 13 , no. 4, p. 542-547. ISSN 12132489

[10] DIN 50190 - part 3: Hardness depth of heat-treated parts; determination of the effective depth of hardening after nitriding.

[11] ČSN 420363 Metal testing. Fatigue testing of metals. Methodology of testing.

[12] ČSN 420368 Metal testing. Fatigue testing of metals. Statistical evaluation of fatigue test results of metals. 